\title{
Cross-Communication Between Acetylcholine and VIP in Controlling Catecholamine Secretion by Affecting cAMP, Inositol Triphosphate, Protein Kinase C, and Calcium in Rat Adrenal Medulla
}

\author{
Ravindra K. Malhotra, Taruna D. Wakade, and Arun R. Wakade \\ Department of Pharmacology, School of Medicine, Wayne State University, Detroit, Michigan 48201
}

\begin{abstract}
The purpose of the present study was to determine the molecular mechanism of stimulatory actions of ACh and vasoactive intestinal polypeptide (VIP) by determining the role of various second messengers in the neurohumoral secretion. Toward such a goal, we measured CAMP, CGMP, protein kinase (PKC) activity, ${ }^{3} \mathrm{H}$-inositol triphosphate $\left({ }^{3} \mathrm{H}-\mathrm{IP}_{3}\right)$, and ${ }^{45} \mathrm{Ca}$ uptake in the adrenal medulla subjected to various treatments. Stimulation of splanchnic nerve endings increased ${ }^{45} \mathrm{Ca}$ uptake, cAMP content, ${ }^{3} \mathrm{H}-\mathrm{IP}$, and PKC activity in the adrenal medulla. If muscarinic receptors of chromatfin cells were selectively activated by perfusion with muscarine, ${ }^{3} \mathrm{H}$ $\mathrm{IP}_{3}$ content and PKC activity were enhanced. Nicotine, on the other hand, increased only ${ }^{45} \mathrm{Ca}$ uptake without affecting any other second messenger. Perfusion with VIP increased PKC activity and $\mathrm{CAMP}$ and ${ }^{\mathrm{H}} \mathrm{H}-\mathrm{IP}_{3}$ content. None of the procedures affected CGMP content. Interplay among various second messengers was further investigated by studying interactions of nicotinic, muscarinic, and VIP-ergic receptors in modulation of catecholamine (CA) secretion and by using agents known to activate specific second messengers (e.g., forskolin, phorbol esters). Our results show that muscarine, VIP, and phorbol ester facilitated nicotine-evoked secretion by increasing PKC activity, and it was associated with an additional increase in ${ }^{45} \mathrm{Ca}$ accumulation. On the other hand, secretion evoked by nicotine as well as muscarine was facilitated by forskolin without additional increase in ${ }^{45} \mathrm{Ca}$ accumulation. A novel feature of the study is that ACh and VIP activate three types of receptors on chromaffin cells to stimulate and mutually facilitate the secretion of CA by generating various second messengers. These second messengers act at different levels to regulate $\mathrm{Ca}$ mobilization and its use in the secretory process.
\end{abstract}

Neurotransmitters and hormones exert their physiological effects by combining with specific receptors present on a cell membrane. Receptor activation results in generation of different types of second messengers, which ultimately leads to a physiological response. In the adrenal medullary synapse, ACh released from splanchnic nerve endings activates cholinergic receptors to induce secretion of catecholamine (CA). Among the known second messengers [i.e., cAMP, cGMP, Ca, protein kinase $\mathrm{C}(\mathrm{PKC})$,

\footnotetext{
Received Dec. 28, 1988; revised Apr. 10, 1989; accepted May 1, 1989.

This work was recently presented at the seventh meeting on Adrenergic Mechanisms, held in Porto, Portugal.

Correspondence should be addressed to Dr. Arun R. Wakade, Department of Pharmacology, Wayne State University, Scott Hall, 540 E. Canfield, Detroit, MI 48201.

Copyright (C) 1989 Society for Neuroscience $0270-6474 / 89 / 124150-08 \$ 02.00 / 0$
}

and inositol triphosphate $\left.\left(\mathrm{IP}_{3}\right)\right]$, only the role of $\mathrm{Ca}$ is well established in the exocytotic secretion of adrenal medullary hormones (Douglas, 1968; Baker and Rink, 1975). The most commonly held view is that the secretory response is directly dependent on the increase in free cytoplasmic concentration of Ca (Douglas, 1968; Kirpekar, 1975).

Experiments aimed at determining the involvement of CAMP and CGMP in the secretory process have yiclded such variable data that a definitive conclusion is impossible at this time. To cite a few examples, cAMP and its analogs stimulated CA secretion without the need of $\mathrm{Ca}$ and either facilitated or did not alter stimulation-induced secretion. The phosphodiesterase inhibitor, theophylline, evoked as well as facilitated the secretion evoked by other agents (Peach, 1972; Guidotti and Costa, 1973; Jannus and Rubin, 1976; Gutman and Boonyavivoj, 1979; Schneider et al., 1979; Tsujimoto et al., 1986).

Effects of forskolin, which enhances cellular cAMP content, are equally variable. Increase in cAMP content has been shown to both inhibit CA secretion (Baker et al., 1985; McHugh and McGee, 1986; Cheek and Burgoyne, 1987) and facilitate CA secretion (Tsujimoto et al., 1986; Wakade et al., 1986; Morita et al., 1987a, b). The role of cGMP in CA secretion is even more difficult to understand, mainly because of contradictory results reported by various investigators. A 5-fold increase in cGMP by ACh was reported in bovine chromaffin cells, implying that cGMP is involved in the secretion (Schneider et al., 1979). However, using a similar test preparation, Derome et al. (1981) showed that cGMP produced by activation of muscarinic receptors inhibited nicotine-evoked CA secretion, whereas Forsberg et al. (1986) showed that stimulation of muscarinic receptors caused facilitation of nicotine receptor-mediated secretion of CA.

Several investigators have shown that muscarinic receptor stimulation leads to formation of ${ }^{3} \mathrm{H}$-inositol phosphates (Oka et al., 1982; Vincentini et al., 1985), but this action was not associated with an exocytotic secretion of CA because of small amounts of Ca released by $\mathrm{IP}_{3}$ from the internal Ca stores (Fisher et al., 1981). Phorbol esters were used to investigate the role of PKC in CA secretion, but these agents did not modify the secretion evoked by nicotine or excess $\mathrm{K}$ from cultured chromaffin cells (Pozzan et al., 1984; Brocklehurst et al., 1985). However, in the perfused adrenal preparations of rat and dog, stimulation of muscarinic receptors enhanced phospholipid hydrolysis and CA secretion (Malhotra et al., 1988b), and activators of PKC facilitated nicotine- and K-evoked secretion (Sorimachi et al., 1985; Wakade et al., 1986).

Chromaffin cells used in these and several other studies were perfused in an intact adrenal gland, dissociated from the adrenal 
medulla and placed in different culture conditions, obtained from a tumor cell line of the adrenal medulla, permeabilized by physical or chemical treatments, etc. Obviously, these differences in experimental preparations, plus the fact that experiments were aimed at examining a role of only one or two second messengers without a concomitant analysis of CA secretion, make it difficult-if not impossible-to know how various second messengers regulate $\mathrm{CA}$ secretion.

We have used the isolated perfused adrenal gland of the rat, which has the distinct advantage of stimulating the chromaffin cells through the splanchic nerve supply (Wakade, 1981a). Stimulation of these nerves liberates ACh and a noncholinergic substance, which we have identificd as VIP (R. K. Malhotra et al., unpublished observations). Using such a preparation, we have attempted to determine a relationship between $\mathrm{CA}$ secretion and five second messengers on stimulation of chromaffin cells by splanchic nerves. A composite picture of an interplay between chromaffin cell membrane receptors and the underlying second messengers in regulation of exocytotic secretion of adrenal medullary hormones is presented.

\section{Materials and Methods}

Retrograde perfusion of the adrenal gland. The left adrenal gland of the male rat $(300-400 \mathrm{gm})$ was perfused retrogradely, as described by Wakade (1981a). In brief, rats were anesthetized with ether, the left renal vein was cannulated, and the tip of the cannula remained near the junction of the renal and adrenal veins. All other blood vessels were ligated. The adrenal gland, along with tied blood vessels and the cannula, was removed from the rat and placed on a metal plate mounted in a lucite chamber. The metal plate was made up of $\mathrm{Ag} / \mathrm{AgCl}$ and served as one of the electrodes for stimulation of the gland, and another plate electrode was placed on top of the gland (see below). The chamber was maintained at $37^{\circ} \mathrm{C}$ by circulating heated water. The gland was perfused at $0.35 \mathrm{ml} /$ min by means of a Sigma motor pump. Perfusate escaped from a slit made in the adrenal capsule and was collected in chilled tubes. The normal perfusion medium was Krebs-bicarbonate solution. The composition of the solution was as follows (mM): $\mathrm{NaCl}, 119 ; \mathrm{KCl}, 4.7 ; \mathrm{CaCl}_{2}$, $2.5 ; \mathrm{MgSO}_{4}, 1.2 ; \mathrm{KH}_{2} \mathrm{PO}_{4}, 1.2 ;$ glucose, $11 ; \mathrm{NaHCO}_{3}, 25$. The solution was constantly bubbled with $95 \% \mathrm{O}_{2}$ plus $5 \% \mathrm{CO}_{2}$, and the pH was 7.4 $\pm 0.1(n=9)$. The solution contained $0.027 \mathrm{mM} \mathrm{Na}$ EDTA and 0.57 mM ascorbic acid to prevent oxidation of CA.

Stimulation of the adrenal gland. Electrical stimulation of the adrenal gland was achieved by connecting the plate electrodes to a Grass stimulator, model S88, specifically wired for transmural stimulation. Stimulation parameters were 300 pulses at $10 \mathrm{~Hz}, 1.0 \mathrm{msec}$ duration, and $100 \mathrm{~mA}$ strength. With this stimulation parameter, we have shown that splanchnic nerve terminals present in the preparation are activated to release their transmitter substance because after chronic denervation the secretory response is almost abolished on electrical stimulation (Wakade, 1981b). In other experiments, various secretagogues were added to the perfusion solution for a given time or injected directly into the perfusion stream to directly stimulate the chromaffin cells.

Collection of perfusate. As a rule, each adrenal preparation was tested for its secretory response by collecting a $5 \mathrm{~min}$ perfusate before stimulation, and another 5 min perfusate after application of 300 pulses at $10 \mathrm{~Hz}$. Only when the evoked secretion was at least 20 times over the spontaneous secretion were these adrenals used for further studies. Fifteen minutes after the initial testing, one 5 min perfusate was collected to measure the spontaneous secretion, and then the gland was stimulated directly either by agonists or via splanchnic nerves. Perfusates were collected every $5 \mathrm{~min}$ to monitor the secretory response, depending on the type of stimulus used. After a specific time period, the medium was changed back to Krebs solution for about a $15 \mathrm{~min}$ period, and in the presence of these agents, perfusates were collected before and after stimulation.

Measurement of catecholamines. CA content of the perfusate was analyzed directly by the fluorometric method of Anton and Sayre (1962) without the intermediate purification of alumina for the reasons given earlier (Wakade, 1981a). The contents of CA in the perfusate were expressed in terms of epinephrine base. Amounts of CA secreted during the nonstimulation period have been subtracted from those secreted in the stimulation period to obtain net secretion. The amounts of CA secreted in the $5 \mathrm{~min}$ nonstimulation period were $6 \pm 3 \mathrm{ng}(n=22)$.

Analysis of second messengers. Adrenal glands were perfused as described above, and after the end of a given stimulus alone or in the presence of other agents, the adrenal gland was quickly removed and placed in ice-cold Krebs solution. The medulla was separated and used for analysis of various second messengers. Other details are given below.

Protein kinase C. PKC was estimated in the adrenal medulla by the method of Kikkawa et al. (1983). In brief, the medulla was homogenized in a Potter-Elvehjem homogenizer, using $1 \mathrm{ml}$ of ice-cold buffer $(20 \mathrm{~mm}$ Tris-HCl, pII 7.5, $2 \mathrm{~mm}$ EDTA, and $50 \mathrm{~mm}$ mercaptoethanol). The homogenate was then centrifuged at $100,000 \mathrm{~g}$ at $4^{\circ} \mathrm{C}$ for $60 \mathrm{~min}$. The supernatant was used for the analysis of PKC and total proteins in cytosolic fraction. The pellet was resuspended in ice-cold buffer $(20 \mathrm{mM}$ Tris- $\mathrm{HCl}$, pH 7.5, 2 mM EDTA, $50 \mathrm{~mm}$ mercaptoethanol, $10 \mathrm{~mm}$ EGTA, and $0.1 \%$ Triton $X-100$ ) and stirred for $30 \mathrm{~min}$ at $4^{\circ} \mathrm{C}$. The solution was centrifuged at $100,000 \mathrm{~g}$ at $4^{\circ} \mathrm{C}$ for $30 \mathrm{~min}$, and the supernatant was used for the assay of PKC and total proteins in particulate fraction. The standard assay mixture (200:1 final volume) contained $20 \mathrm{~mm}$ Tris$\mathrm{HCl}(\mathrm{pH} 7.5), 5 \mathrm{~mm} \mathrm{Mg}\left(\mathrm{CH}_{3} \mathrm{COO}\right)_{2}, 250 \mathrm{~mm}$ EGTA, 4 gm phosphatidylserine, $0.1 \mathrm{gm}$ dioleins, $20 \mathrm{gm}$ histone-type III S, $10 \mathrm{M}$ ATP (1 Ci of $\gamma={ }^{32} \mathrm{P}-\mathrm{ATP} /$ assay, specific activity $11.7 \mathrm{Ci} / \mathrm{mmol}$ ), and the enzyme (cytosolic or particulate fraction equivalent to $20-30 \mathrm{gm}$ protein). To the mixture of particulate fraction $2.1 \mathrm{mM} \mathrm{CaCl}_{2}$ was added to neutralize the effect of EGTA present in the homogenization buffer. The control (sample blank) was without $\mathrm{Ca}$, phosphatidylserine, and dioleins, and instead of $\mathrm{CaCl}_{2}, 0.5 \mathrm{mM}$ EGTA was added to the assay mixture. Incubation was carried out at $37^{\circ} \mathrm{C}$ for $3 \mathrm{~min}$. Reaction was terminated by addition of $200 \mu \mathrm{l}$ of BSA $(10 \mathrm{mg} / \mathrm{ml})$ and $1 \mathrm{ml}$ of $10 \%$ trichloracetic acid (TCA). The tubes were centrifuged at approximately $1000 \mathrm{~g}$ for 10 min. Supernatant was discarded, and the pellet containing phosphoproteins was dissolved in $1.0 \mathrm{ml}$ of $\mathrm{NaOH}(0.5 \mathrm{M})$. The phosphoproteins were reprecipitated by adding $1.0 \mathrm{ml}$ TCA $(10 \%)$, and the procedure was repeated four times. Finally, the pellet was dissolved in $1.0 \mathrm{ml}$ of $0.5 \mathrm{M} \mathrm{NaOH}$ and used for counting the radioactivity. In each group, counts obtained in the absence of $\mathrm{Ca}$, phospholipid, and dioleins have been subtracted from those obtained in the presence of all the cofactors to determine the counts that represent the incorporation of ${ }^{32} \mathrm{P}$ from $\gamma^{-32} \mathrm{P}$-ATP into calf thymus histone by PKC. Values of $\mathrm{cpm}$ were then converted to picomoles using the specific activity of $\gamma_{-32}{ }^{2} \mathrm{P}-\mathrm{ATP}$. The enzyme activity in the particulate and cytosol fraction is expressed as picomoles per minute per milligram of protein. Several other details of the assay are given in earlier publications (Malhotra et al., 1988a; Wakade et al., 1988).

CAMP and $C G M P$. The adrenal medulla was homogenized in $10 \%$ icecold TCA. After centrifugation, the clear supernatant was treated 4 times with water-saturated ether to remove TCA. The final extract was evaporated to dryness in a Buchler rotary evaporator and then reconstituted in $0.5 \mathrm{ml}$ of sodium acetate buffer ( $\mathrm{pH} \mathrm{6.2)} \mathrm{and} \mathrm{used} \mathrm{to} \mathrm{measure} \mathrm{cAMP}$ and cGMP contents, using the radioimmunoassay kits from the New England Nuclear Corp., Boston, MA. Each sample was run in duplicate, and the averaged values from separate experiments were pooled.

${ }^{45} \mathrm{Ca}$ uptake. The uptake of ${ }^{45} \mathrm{Ca}$ was measured in the rat adrenal medulla as described previously (Wakade et al., 1986). The adrenal gland was perfused with Krebs solution for $30 \mathrm{~min}$. The medium was then changed to Krebs solution containing $0.5 \mathrm{mg} / \mathrm{ml}{ }^{45} \mathrm{Ca}\left(\right.$ as ${ }^{45} \mathrm{CaCl}_{2}$, specific activity $23.69 \mathrm{mCi} / \mathrm{mg}$ ) for $10 \mathrm{~min}$. The gland was perfused for $30 \mathrm{~min}$ with ice-cold Krebs solution. An identical protocol was carried out in other adrenal glands, except that the $10 \mathrm{~min}$ perfusion with ${ }^{45} \mathrm{Ca}$ Krebs solution contained various secretagogues or electrical stimulation was applied in this period. In another series of experiments, this protocol was carried out except that before exposure to ${ }^{45} \mathrm{Ca}$ medium, the adrenal gland was perfused with Krebs solution containing test agents for 15 $\mathrm{min}$, and in their presence, the gland was perfused with ${ }^{45} \mathrm{Ca}$ medium alone or that containing a stimulatory agent. After the $30 \mathrm{~min}$ wash period, the gland was removed, the adrenal medulla was separated, weighed, and homogenized in $1 \mathrm{ml}$ of $0.05 \mathrm{M}$ perchloric acid, the homogenate was centrifuged, and the supernatant $(0.5 \mathrm{ml})$ was counted in a liquid scintillation counter (Beckman, Model LS7000). Total counts after correction for dilution and quenching were converted to picograms and expressed as picograms per milligram of the protein content of the adrenal medulla.

${ }^{3} \mathrm{H}$-Inositol phosphates. The adrenal gland was labeled with ${ }^{3} \mathrm{H}$-Inosi- 


\section{Stimulation via splanchnic neurons $(10 \mathrm{~Hz})$}

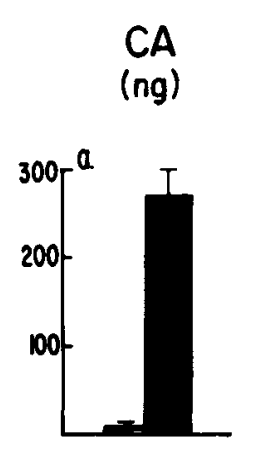

\author{
$\mathrm{Ca}^{45}$ \\ $(\mathrm{pg} / \mathrm{mg})$
}

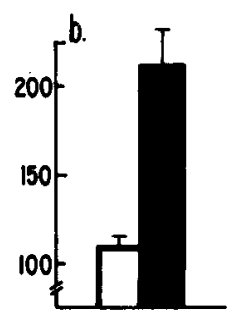

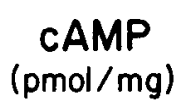

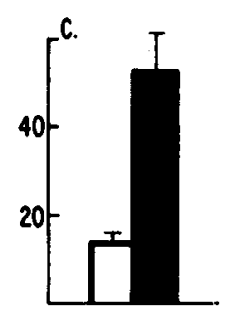

\author{
${ }^{3} \mathrm{H}-1 \mathrm{P}_{3}$ \\ (cpm/mg)
}

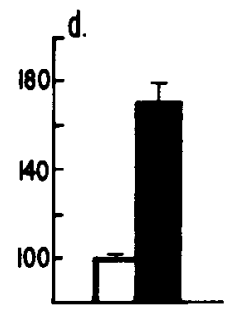

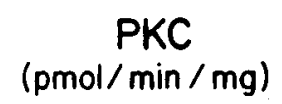

$\underset{(\mathrm{pmol} / \mathrm{mg})}{\mathrm{cGMP}}$
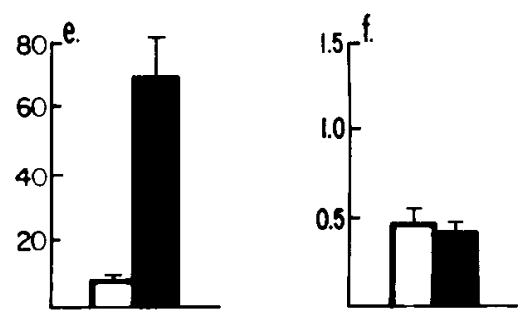

\section{Stimulation by $\mathrm{ACh}$ or VIP( $\mu \mathrm{M})$}
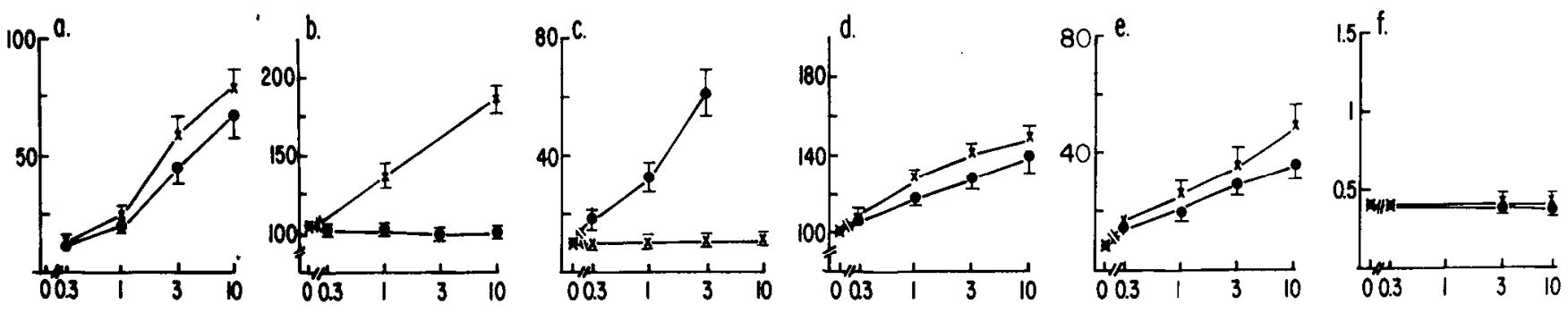

Figure 1. Effect of field stimulation, ACh, and VIP on CA secretion and five second messengers. I, The general protocol of these experiments was as follows. The adrenal gland was perfused for $30 \mathrm{~min}$ with Krebs solution and removed for analysis of second messengers (open columns). In other sets, the gland was perfused for $20 \mathrm{~min}$ and then stimulated for $10 \mathrm{~min}$ at $10 \mathrm{~Hz}$ before removal for analysis (solid columns). II, Increasing concentrations of ACh $(x)$ or VIP $(O)$ were injected in the perfusion stream to evoke CA secretion and generate second messengers. Different adrenals were used for each point shown in $b$ through $f$. Each column and point is a mean of 3-18 observations. Vertical lines show SEM.

tol $\left(30 \mu \mathrm{l}\right.$ of ${ }^{3} \mathrm{H}$-myoinositol, specific activity $17.1 \mathrm{Ci} / \mathrm{mmol}$ in $3 \mathrm{ml}$ Krebs) by recirculating the solution for $1 \mathrm{hr}$, followed by washout with Krebs solution for $45 \mathrm{~min}$ and then $15 \mathrm{~min}$ with lithium chloride-Krebs solution. The control gland was removed after $10 \mathrm{~min}$, and the medulla was separated and then processed for estimation of ${ }^{3} \mathrm{H}-\mathrm{IP}_{3}$. The experimental glands were perfused with stimulatory agent for $10 \mathrm{~min}$ or received electrical stimulation $(10 \mathrm{~Hz}$ for $10 \mathrm{~min})$ and then were removed for the analysis. The medulla was separated and homogenized in $0.5 \mathrm{ml}$ of $10 \%$ TCA. After centrifugation ( $9500 \mathrm{rpm}$ for $15 \mathrm{~min}$ ), the pellet was used for protein estimation, and the supernatant was neutralized with $\mathrm{NaOH}$ and placed on a resin (AG 1-X8, 200-400 mesh formate) form. ${ }^{3} \mathrm{H}$-Inositol monophosphate (IP), ${ }^{3} \mathrm{H}$-inositol diphosphate $\left(\mathrm{IP}_{2}\right)$, and ${ }^{3} \mathrm{H}-\mathrm{IP}_{3}$ were then successively eluted with $5 \mathrm{ml}$ each of $0.18 \mathrm{M}, 0.6 \mathrm{M}$, and $1.2 \mathrm{M}$ ammonium formate $/ 0.1 \mathrm{M}$ formic acid, respectively. The radioactivity in each $5 \mathrm{ml}$ eluate was determined in a liquid scintillation counter and was expressed as counts per minute per milligram of protein.

Proteins. In the case of cyclic nucleotides and ${ }^{3} \mathrm{H}$-inositol phosphates, the TCA extract was centrifuged, and the pellet was resuspended in 1 $\mathrm{N} \mathrm{NaOH}$ and used for protein estimation, as described by Schacterle and Pollack (1983). In the case of PKC, total proteins in cytosol and particulate fractions were measured by using the Bio-Rad protein assay because Triton used in the buffer interfered with Schacterle and Pollack's method.

Statistical analysis. All data are presented as means with standard errors, and statistical comparisons are made using Student's $t$-test.

Drugs and chemicals used. The following drugs and chemicals were used in these experiments: muscarine chloride, nicotine, ACh bromide, vasoactive intestinal polypeptide (VIP), sodium nitroprusside, 3-isobutyl-1-methylxanthine (all from Sigma Chemical Corp., St. Louis, MO), phorbol 12,13-dibutyrate (LC Services, Woburn, MA), and forskolin (Calbiochem, San Diego, CA).

\section{Results}

Effects of splanchnic nerve stimulation, $A C h$, and VIP on $C A$ secretion and second messengers

Stimulation of splanchnic nerve terminals $(10 \mathrm{~Hz}$ for $10 \mathrm{~min})$ produced a large increase in the secretion of CA. The secretory response was associated with a substantial increase in ${ }^{45} \mathrm{Ca}$ uptake, cAMP and ${ }^{3} \mathrm{H}-\mathrm{IP}_{3}$ contents, and PKC activity. cGMP content was unaffected (Fig. 1I). Since stimulation of splanchnic nerves liberates ACh and VIP as neurotransmitters and both are activators of the rat chromaffin cells (Malhotra and Wakade, 1987a, b; Wakade, 1988), the effects of exogenous ACh and VIP on CA secretion and second messengers were investigated (Fig. $1 I I)$. ACh and VIP stimulated CA secretion in a concentrationdependent manner. However, their effects on second messengers were quite variable. For instance, $\mathrm{ACh}$ increased ${ }^{45} \mathrm{Ca}$ uptake, ${ }^{3} \mathrm{H}-\mathrm{IP}{ }_{3}$ content, and $\mathrm{PKC}$ activity without affecting the cAMP content. On the other hand, contents of cAMP and ${ }^{3} \mathrm{H}-\mathrm{IP}_{3}$ and the activity of PKC were increased by VIP without affecting ${ }^{45} \mathrm{Ca}$ uptake. Neither agent had any effect on cGMP content.

Coupling of nicotinic, muscarinic, and VIP-ergic receptors to second messengers

Since ACh activates nicotinic and muscarinic receptors of the rat adrenal medulla (Wakade and Wakade, 1983), it was of further interest to examine which type of receptor was respon- 


\begin{tabular}{|c|c|c|c|c|c|c|}
\hline +Muscarine (100 $\mu \mathrm{M})$ & $12.4 \pm 2.92$ & $182.1 \pm 6.8^{*}$ & $62.8 \pm 1.0^{*}$ & $0.50 \pm 0.04$ & $1.07 \pm 0.08$ & $1.88 \pm 0.18^{*}$ \\
\hline+ Nicotine $(12 \mu \mathrm{M})$ & $11.36 \pm 1.54$ & $106 \pm 5.2$ & $9.2 \pm 0.6$ & $0.53 \pm 0.11$ & $2.24 \pm 0.18^{*}$ & $2.65 \pm 0.46^{*}$ \\
\hline +VIP $(10 \mu \mathrm{M})$ & $83.66 \pm 7.0$ & $146 \pm 8.8^{*}$ & $18.4 \pm 2.4^{*}$ & $0.55 \pm 0.033$ & $1.04 \pm 0.09$ & $0.73 \pm 0.05^{*}$ \\
\hline +Muscarine & $114.5 \pm 25.18$ & $190 \pm 10.6^{* *}$ & $61.6 \pm 8.4^{* *}$ & - & $1.26 \pm 0.06$ & $3.51 \pm 0.46^{*}$ \\
\hline+ Nicotine & $94.33 \pm 8.90$ & $92.2 \pm 8.6$ & $11.2 \pm 2.2$ & - & $2.21 \pm 0.19^{* *}$ & $4.16 \pm 0.60^{*}$ \\
\hline+ VIP & $181.75 \pm 29.06^{* *}$ & $140.6 \pm 11.2^{* *}$ & $20.2 \pm 2.8^{* *}$ & - & $0.98 \pm 0.20$ & $1.38 \pm 0.08^{*}$ \\
\hline Phorbol 12, 13-dibutyrate (30 nM) & $11.6 \pm 1.8$ & $104.6 \pm 10.2$ & $61.0 \pm 1.4^{*}$ & $0.44 \pm 0.06$ & $1.23 \pm 0.15$ & $0.11 \pm 0.01$ \\
\hline +Muscarine & $13.2 \pm 2.6$ & $148.2 \pm 8.6^{* * *}$ & $68.8 \pm 2.8$ & - & $1.18 \pm 0.10$ & $2.02 \pm 0.30^{* *}$ \\
\hline + Nicotine & $10.4 \pm 4.1$ & $98.2 \pm 3.8$ & $65.0 \pm 5.6$ & - & $3.02 \pm 0.28^{* * *}$ & $5.63 \pm 0.64^{*}$ \\
\hline +VIP & - & - & - & $2.24 \pm 0.14$ & - & $0.80 \pm 0.04$ \\
\hline
\end{tabular}

The basic protocol was similar to that described for Figure 1, except that the effects of muscarine, nicotine, and VIP were tested in the absence and presence of other agents that are known to increase specific second messengers. The adrenal gland was perfused with test agents for 15 min and then removed for the analysis of different messengers. In the others, after the pretreatment with test agents for $15 \mathrm{~min}$, the adrenals were removed for assay. The same concentrations of agonists shown in the control group (none) were used in other experiments. Each adrenal gland yielded one observation point, and each value is a mean \pm SEM of 3-8 observations. The mg unit applies to the protein content of the adrenal medulla.

* Compare to control (none), $p<0.01$.

** Compare to IBMX + forskolin, $p<0.01$.

** Compare to phorboil 12,13-dibutyrate, $p<0.0005$.

sible for generating second messengers after ACh stimulation. As shown in Table 1, activation of muscarinic receptors by muscarine increased CA secretion, ${ }^{3} \mathrm{H}-\mathrm{IP}_{3}$ content, and PKC activity. Muscarine had no effect on ${ }^{45} \mathrm{Ca}$ uptake and cyclic nucleotides. Nicotine, on the other hand, increased CA secretion and ${ }^{45} \mathrm{Ca}$ uptake without affecting any other second messenger. Table 1 also shows that VIP enhanced CA secretion, along with substantial increases in PKC activity and cAMP and ${ }^{3} \mathrm{H}-\mathrm{IP}_{3}$ contents. VIP did not affect cGMP content.

\section{Specificity of cholinergic receptors}

Effects of nicotinic and muscarinic receptor antagonists were investigated on $\mathrm{ACh}$-induced increase in ${ }^{45} \mathrm{Ca}$ accumulation and ${ }^{3} \mathrm{H}-\mathrm{IP}$ formation. Figure 2 shows that a nicotinic receptor antagonist, mecamylamine $(0.35 \mathrm{~mm})$ produced over $90 \%$ inhibition of ${ }^{45} \mathrm{Ca}$ accumulation but had no effect on ${ }^{3} \mathrm{H}-\mathrm{IP}$ production. On the other hand, atropine $(0.5 \mu \mathrm{M})$ completely inhibited ${ }^{3} \mathrm{H}$-IP production but had no effect on ${ }^{45} \mathrm{Ca}$ accumulation. When the medulla was stimulated with $\mathrm{ACh}$ in the presence of atropine and mecamylamine, production of ${ }^{3} \mathrm{H}$-IP and accumulation of ${ }^{45} \mathrm{Ca}$ were almost completely blocked. These results are consistent with our earlier reports on the specificity of agonists and antagonists in the rat adrenal medulla (Wakade and Wakade, 1983; Wakade, 1987).

\section{Effects of forskolin and phorbol ester on $C A$ secretion and second messengers in the absence and presence of agonists}

Pharmacological agents known to increase second messengers were tested alone and in combination with other secretagogues for their effects on CA secretion and second messengers. Forskolin plus the phosphodiesterase inhibitor, 3-isobutyl-1-methylxanthine (IBMX) (Amer and Kreighbaum, 1975) enhanced
cAMP content by almost tenfold without modifying any other second messenger and CA secretion (Table 1 ). This pretreatment resulted in a facilitation of CA secretion evoked only by nicotine, muscarine, and VIP. cAMP content was not further enhanced, except in the case of VIP-treated tissues. Phorbol 12,13-dibutyrate (PDB) stimulated the PKC activity by about eightfold, but the other constituents were unaffected. Pretreatment with PDB caused facilitation of CA secretion evoked only by nicotine. The secretory response to muscarine and VIP was unaffected by the PDB. Although none of the cholinergic agonists, and VIP alone or in combination with other agents, affected cGMP, sodium nitroprusside was effective in increasing its content. Sodium nitroprusside had no effect on CA secretion (not shown).

\section{Interactions among nicotinic, muscarinic, and VIP-ergic receptors in modulation of $C A$ secretion}

Since nicotinic receptor-mediated secretion of $\mathrm{CA}$ is facilitated by PDB, which activates PKC, and since muscarinic receptor stimulation also activates PKC (Table 1), it was of great interest to study the interaction between nicotinic and muscarinic receptors on CA secretion. Secretion induced by a fixed concentration of nicotine was facilitated by 10 and $30 \mu \mathrm{M}$ muscarine (Fig. 3). Higher concentration had no additional effect. Since VIP also enhances PKC activity (Table 1), we examined the effects of VIP on CA secretion evoked by ACh. Each concentration of VIP facilitated the secretion of CA evoked by different concentrations of ACh (Fig. 4). To determine the underlying receptors involved in the facilitation of ACh's action by VIP, further experiments were carried out with VIP and muscarine and VIP and nicotine. As shown in Figure 5, VIP-evoked secretion was additive and not facilitated by any concentration of muscarine. On the other hand, nicotine-evoked secretion was 


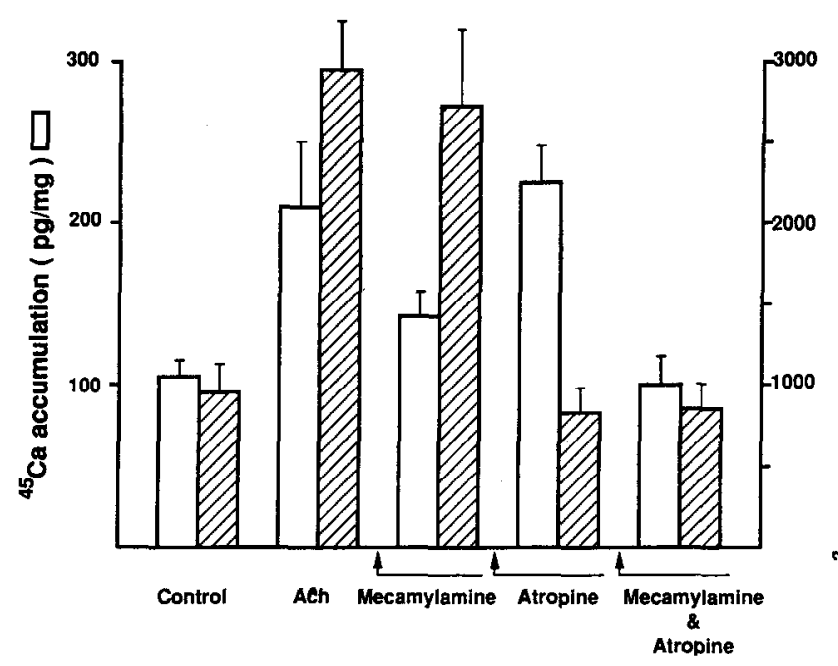

Figure 2. Specificity of nicotinic and muscarinic receptors. Accumulation of ${ }^{45} \mathrm{Ca}$ and ${ }^{3} \mathrm{H}$-IP formation were studied by using mecamylamine and atropine. ${ }^{45} \mathrm{Ca}$ accumulation (open columns) and ${ }^{3} \mathrm{H}$-IP formation (hatched columns) were measured in the absence (control) or presence of $\mathrm{ACh}(10 \mu \mathrm{M})$. ACh-induced ${ }^{45} \mathrm{Ca}$ accumulation was then studied in the presence of atropine $(0.5 \mu \mathrm{M})$ and mecamylamine $(0.35 \mathrm{~mm})$ alone or together. Each column is a mean of 3 experiments. Vertical lines show SEM.

facilitated by about 2 -fold by VIP pretreatment (data not shown but identical to those shown for muscarine in Fig. 3).

\section{Role of $\mathrm{Ca}$ in $\mathrm{CA}$ secretion evoked by different agonists}

One of the noteworthy features of the present test preparation is that activation of nicotinic receptors increases the influx of extracellular $\mathrm{Ca}$, whereas muscarinic receptor activation mobilizes mostly the internal Ca (Wakade et al., 1986; Malhotra et al., 1988c). This special property allows us to test the importance of extracellular vs. intracellular $\mathrm{Ca}$ sources for $\mathrm{CA}$ secretion, using the three receptor-mediated mechanisms described. We compared CA secretion mediated by stimulation of three types of receptors in normal and Ca-free medium before

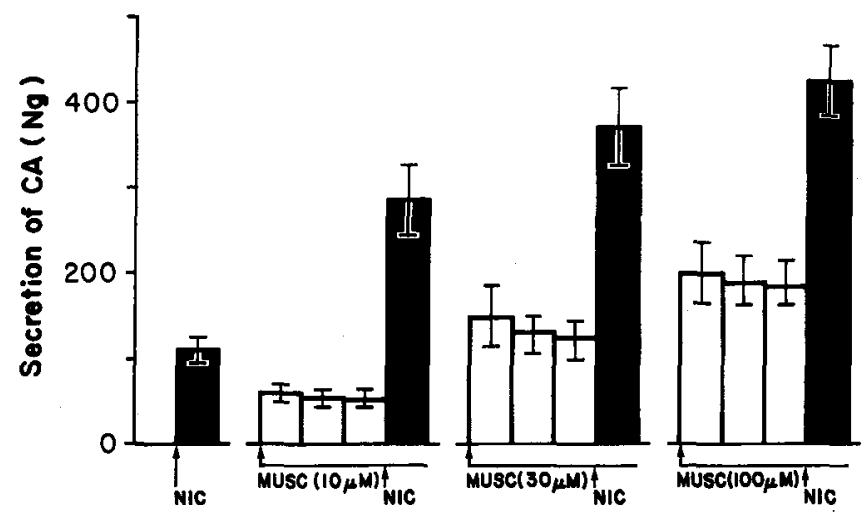

Figure 3. Interaction between nicotine and muscarine on CA secretion. Secretion of CA was evoked by injecting a slug of nicotine (NIC, 0.3 $\mu \mathrm{g}$ ) into the normal perfusion medium. After $15 \mathrm{~min}$, the medium was switched over to muscarine (MUS) for $15 \mathrm{~min}$, and in its presence, nicotine was injected. The procedure was repeated after $30 \mathrm{~min}$ intervals with increasing concentrations of muscarine, as shown. Each column represents CA secreted in $5 \mathrm{~min}$. Spontaneous secretion of CA $(6 \pm 3$ $\mathrm{ng}, n=22$ ) was subtracted from the evoked secretion of CA. Each column is a mean of 7 experiments. Vertical lines show SEM.

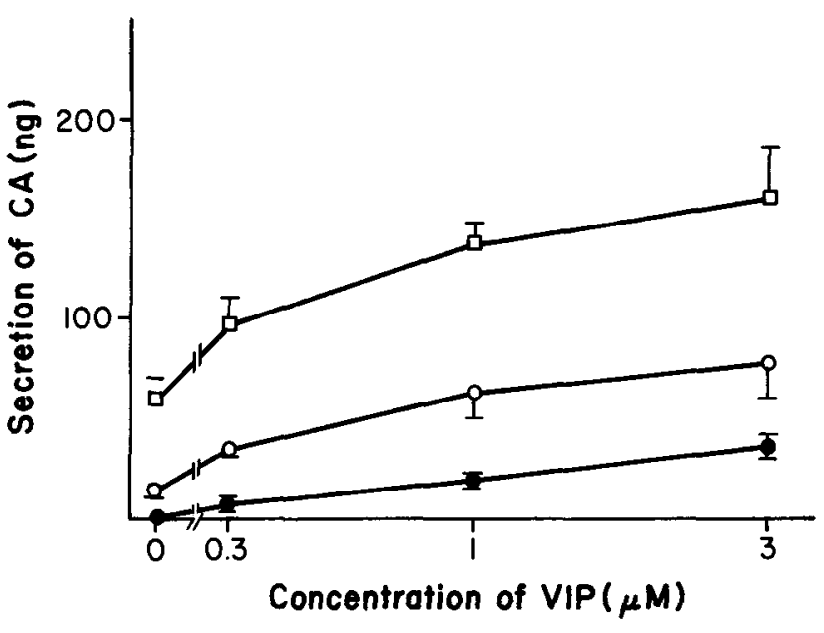

Figure 4. Interaction bctween ACh and $\mu \mathrm{VIP}$ on CA secretion. Secretion of CA was evoked by perfusion with $1 \mu \mathrm{m}$ (open circles) and 10 $\mu \mathrm{M}$ (squares) $\mathrm{ACh}$ in the absence and in the presence of increasing concentrations of VIP, as shown. Secretion evoked by VIP is shown by solid circles. Each concentration of VIP was in contact with the adrenal gland for $5 \mathrm{~min}$ before $\mathrm{ACh}$ exposure. Each point is a mean of $4 \mathrm{ex}$ periments. Vertical lines show SEM.

and after activation of specific second messengers (Fig. 6). In normal medium (2.5 mM Ca), nicotine-evoked secretion was slightly but significantly facilitated by IBMX $(60 \%, p<0.01)$. IBMX plus forskolin produced a much greater facilitation (over $200 \%, p<0.0001$ ). Addition of PDB caused even greater facilitation (about 450\%, $p<0.001$ ). Muscarine-evoked secretion was also facilitated by IBMX and forskolin to the same extent as seen with nicotine, but PDB had no effect. Although the magnitude of facilitation was considerably less with VIP, the results were qualitatively similar to those obtained with muscarine. After removal of $\mathrm{CaCl}_{2}$ from the perfusion medium, the nicotinic response was depressed by over $80 \%$. In vivid contrast, the secretion of CA evoked by muscarine or VIP persisted in Ca-free medium, and the facilitatory effects of the various drug pretreatments on such secretion were still present.

\section{Discussion}

Our ongoing experiments show that VIP-like radioimmunoreactivity is released in the perfusate of the rat adrenal gland after stimulation of splanchnic nerves, and the effect is abolished in chronically denervated adrenals (Malhotra et al., unpublished observations). These results taken together with our previous work (Malhotra and Wakade, 1987a, b) show that VIP is released in addition to ACh in the adrenal medullary synapse to activate various types of receptors of the chromaffin cells. Here we show that activation of various receptors causes changes in 4 second messengers. For example, activation of nicotinic receptors increased only ${ }^{45} \mathrm{Ca}$ uptake, and muscarinic receptor activation increased ${ }^{3} \mathrm{H}-\mathrm{IP}_{3}$ content and $\mathrm{PKC}$ activity, whereas activation of VIP receptors increased cAMP and ${ }^{3} \mathrm{H}-\mathrm{IP}_{3}$ content and $\mathrm{PKC}$ activity. This is the first demonstration in which secretion of CA evoked by physiological stimulation of chromaffin cells was associated with elevation of 4 second messengers. A model representing interaction within the chromaffin cell of these various second messengers is shown in Figure 7. Activation of nicotinic receptors by $\mathrm{ACh}$ opens $\mathrm{Ca}$ channels, leading to elevation of free intracellular $\mathrm{Ca}$ concentration. Activation of muscarinic receptors by $\mathrm{ACh}$ generates $\mathrm{IP}_{3}$ and diacylglycerol 


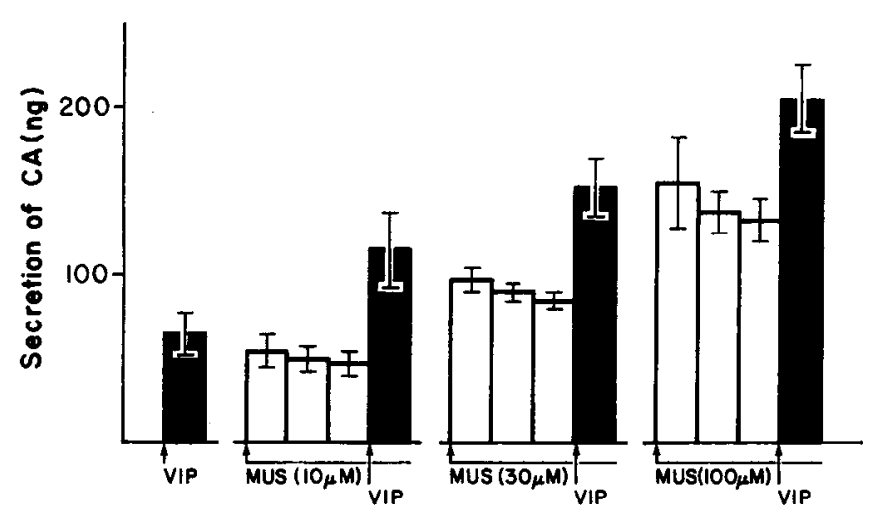

Figure 5. Interaction between VIP and muscarine on CA secretion. The experimental protocol was identical to that described in Figure 3, except that nicotine was replaced by $10 \mu \mathrm{g}$ VIP. Each column is a mean of 4 experiments. Vertical lines show SEM.

(DAG). $\mathrm{IP}_{3}$ mobilizes membrane-bound $\mathrm{Ca}$ to raise free intracellular Ca concentration, whereas DAG plus Ca activate PKC. Activated $\mathrm{PKC}$ regulates $\mathrm{Ca}$ channels (which are already opened by nicotinic receptor activation) in such a way that more extracellular $\mathrm{Ca}$ enters the cell to further raise the intracellular pool of free $\mathrm{Ca}$. Stimulation of VIP receptors increases DAG activity and $\mathrm{IP}_{3}$ and cAMP contents. DAG activates PKC, but such an action does not lead to $\mathrm{Ca}$ mobilization from an outside source because the $\mathrm{Ca}$ channels are not opened by activation of VIP receptors. However, generation of $\mathrm{IP}_{3}$ mobilizes intracellularly bound $\mathrm{Ca}$, which can trigger exocytosis. Increase in cAMP content by forskolin plus IBMX does not lead to CA secretion, implying that increase in cAMP alone cannot initiate exocytosis unless a concomitant rise in free cellular $\mathrm{Ca}$ occurs. VIP has an ability to increase cAMP content and also raise free $\mathrm{Ca}$ concentration by generating $\mathrm{IP}_{3}$. These combined effects lead to secretion of CA. Similarly, PDB treatment cannot cause CA release, but $\mathrm{PDB}$ potentiates nicotine-induced $\mathrm{CA}$ release because nicotine receptor-mediated opening of Ca channels is positively regulated by activated PKC, thereby intensifying the resultant CA release mechanism.

We believe cAMP acts at a distal step of the exocytotic process because facilitation of CA secretion induced by nicotine or muscarine is not associated with additional gain in ${ }^{45} \mathrm{Ca}$ uptake. In fact, IBMX plus forskolin facilitated CA secretion induced by muscarine in the absence of external $\mathrm{Ca}$. These data strongly support our suggestion that cAMP effects those steps of exocytosis that are distal to $\mathrm{Ca}$ mobilization. Since $\mathrm{PDB}$ enhances ${ }^{45} \mathrm{Ca}$ uptake to account for nicotinic action on $\mathrm{CA}$ secretion, we believe that PKC effects early steps of exocytosis (i.e., $\mathrm{Ca}$ mobilization). More direct evidence by measuring $\mathrm{Ca}$ transients in the absence and presence of activation of cAMP and PKC is essential to test this hypothesis.

The unique feature of this model is that the actions of $\mathrm{ACh}$ and VIP on the chromaffin cell have a built-in facilitatory mechanism by generating more than one second messenger. In the case of $\mathrm{ACh}$, activation of nicotinic receptors opens $\mathrm{Ca}$ channels to allow the influx of external $\mathrm{Ca}$. Activity of $\mathrm{Ca}$ channels is positively regulated by $\mathrm{PKC}$ generated by activation of muscarinic receptors. The nct cffect is an additional increase in the influx of $\mathrm{Ca}$. Still another pathway that contributes to a rise in cellular $\mathrm{Ca}$ is via mobilization of intracellular $\mathrm{Ca}$ by $\mathrm{IP}_{3}$ generated by activation of muscarinic receptors. We have shown
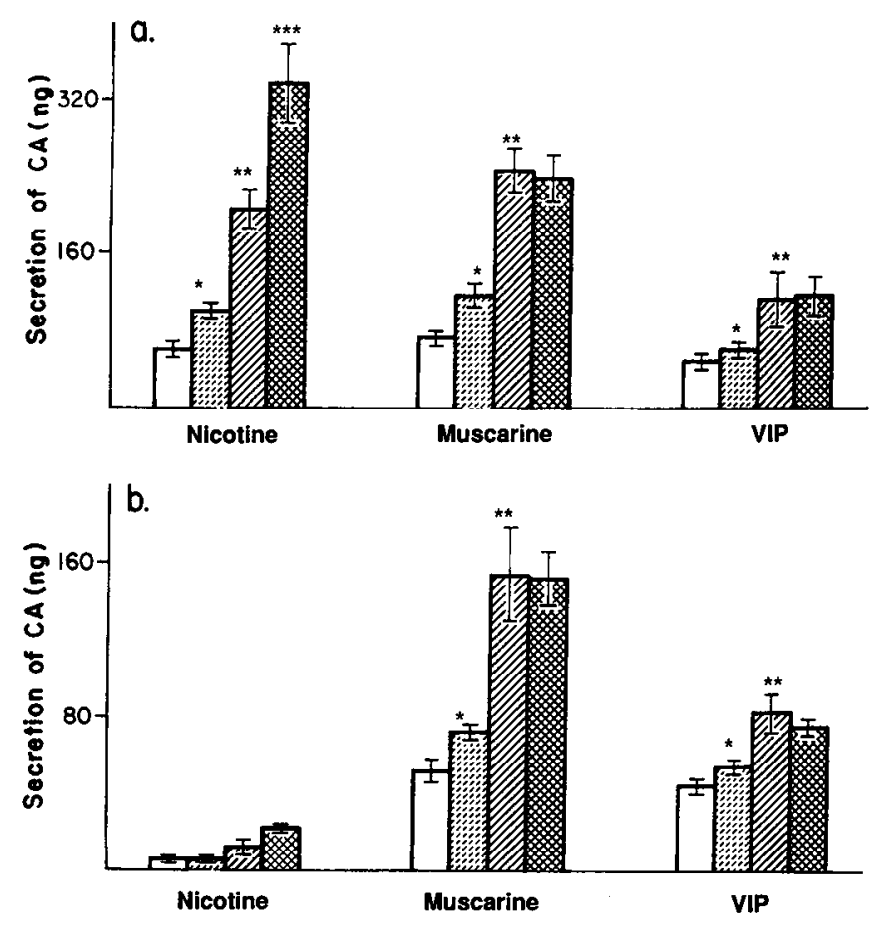

Figure 6. Role of extracellular $\mathrm{Ca}$ in the secretion of $\mathrm{CA}$ evoked by nicotine, muscarine, and VIP after elevation of cAMP and PKC activity. $a$, Secretion of CA was evoked by injecting $0.3 \mu \mathrm{g}$ nicotine first in Krebs solution (open column) and then in Krebs solution containing $10 \mu \mathrm{M}$ IBMX (dotted column), IBMX plus $10 \mu \mathrm{M}$ forskolin (hatched column), and finally in IBMX plus forskolin and $30 \mathrm{nM}$ PDB (cross-hatched column). In other glands, the same protocol was repeated, using muscarine and VIP as stimulatory agents. $b$, The secretion was evoked by nicotine, muscarine, and VIP in $\mathrm{CaCl}_{2}$-free $\mathrm{Krebs}$ solution in the absence and presence of IBMX, forskolin, and PDB, as described in $a$. Each sample was collected for $5 \mathrm{~min}$. Spontaneous secretion of CA $(6 \pm 4$ $\mathrm{ng}, n=20$ ) was subtracted from the evoked secretion. Each column is a mean of 5 experiments. Vertical lines show SEM. *Compare to open column, $p<0.01{ }^{* *}$ Compare to dotted column, $p<0.005 .{ }^{* * *}$ Compare to hatched column, $p<0.005$.

that muscarinic receptor stimulation actually facilitates $\mathrm{CA}$ secretion evoked by nicotine. Since $\mathrm{ACh}$ activates both types of receptors, the evoked secretion is a consequence of interactions of second messengers generated by nicotinic and muscarinic receptors. Lack of effect of nerve stimulation, muscarine, and other agents on cGMP eliminates the involvement of this second messenger in CA secretion in the rat adrenal medulla. Rabe et al. (1987) also have reported that muscarine did not increase cGMP in PC12 cells.

In addition to acting as a neurotransmitter to evoke secretion of CA, VIP also acts as modulator of CA secretion by enhancing the effects of ACh on chromaffin cells. VIP increases PKC activity, which can regulate the influx of $\mathrm{Ca}$ through $\mathrm{Ca}$ channels opened by activation of nicotinic receptors by $\mathrm{ACh}$ so that more $\mathrm{Ca}$ can enter the cell through $\mathrm{Ca}$ channels to facilitate the secretory mechanism. VIP increases cAMP content, which can potentiate exocytosis initiated by the action of $\mathrm{ACh}$ on muscarinic and nicotinic receptors. In support, we have found that there was a synergism between the effects of VIP and ACh on CA secretion on two separate signalling pathways. Whether these effects of VIP are mediated through different VIP receptors on chromaffin cells is not yet clear. Misbahuddin et al. (1988) reported stimulatory effects of VIP on CA secretion and phospholipid hydrolysis in chromaffin cells. 


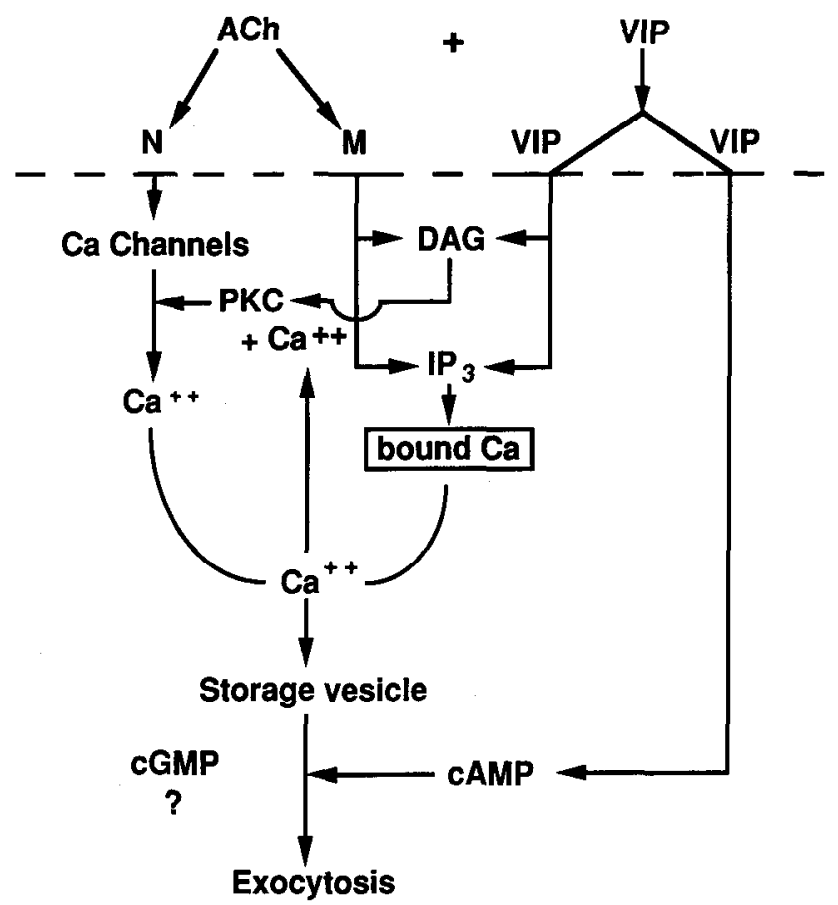

Figure 7. Schematic presentation of the involvement of neurotransmitters, membrane receptors, and second messengers in the exocytotic secretion of CA. ACh and VIP are released after stimulation of splanchnic neurons. $N, M$, and VIP on chromaffin cell represent nicotinic, muscarinic, and VIP-ergic receptors, respectively. $D A G$, diacylglycerol.

In summary, we have presented a detailed picture of how $A C h$ and VIP released from splanchnic nerve terminals lead to a final secretory response of chromaffin cells. A novel feature is that these transmitters act on three different receptors on chromaffin cells to stimulate and mutually facilitate the secretion of CA by generating various second messengers. Since chromaffin cells have proven to be a useful model in understanding the molecular mechanisms involved in synthesis, storage, and release of CA, the present scheme may be of some importance in expanding our knowledge of more heterogeneous neuronal circuits in the CNS.

\section{References}

Amer, M. S., and W. E. Kreighbaum (1975) Cyclic nucleotide phosphodiesterases: Properties, activators, inhibitors, structure-activity relationships and possible role in drug development. J. Pharm. Sci. 64: 1-37.

Anton, A. H., and D. R. Sayre (1962) A study of the factors affecting the alumina oxide, trihydroxyindole procedure for the analysis of catecholamines. J. Pharmacol. Exp. Ther. 138: 360-375.

Baker, E. M., T. R. Cheek, and R. D. Burgoyne (1985) Cyclic AMP inhibits secretion from bovine adrenal cells evoked by carbamylcholine but not by high $\mathrm{K}^{+}$. Biochim. Biophys. Acta 846: 388-393.

Baker, P. F., and T. J. Rink (1975) Catecholamine release from bovine adrenal medulla in response to maintained depolarization. J. Physiol. 253: 593-620.

Brocklehurst, K. W., K. Morita, and H. B. Pollard (1985) Characterization of protein kinase $\mathrm{C}$ and its role in catecholamine secretion from bovine adrenal-medullary cells. Biochem. J. 228: 35-42.

Cheek, T. R., and R. D. Burgoyne (1987) Cyclic AMP inhibits both nicotine-induced action disassembly and catecholamine secretion from bovine adrenal chromaffin cells. J. Biol. Chem. 262: 11663-11666.

Derome, G., R. Tseng, P. Mercier, I. Lamaire, and S. Lemaire (1981) Possible muscarinic regulation of catecholamine secretion mediated by cyclic GMP in isolated bovine adrenal chromaffin cells. Biochem. Pharmacol. 30: 855-860.
Douglas, W. W. (1968) Stimulation-secretion coupling: The concept and clues from chromaffin and other cells. Br. J. Pharmacol. 34: 451474.

Fisher, S. K., R. W. Holz, and B. W. Agranoff (1981) Muscarinic receptors in chromaffin cell cultures mediate enhanced phospholipid labeling but not catecholamine secretion. J. Neurochem. 37: 491499.

Forsberg, E. J., E. Rojas, and H. B. Pollard (1986) Muscarinic receptor enhancement of nicotine-induced catecholamine secretion may be mediated by phosphoinositide metabolism in bovine adrenal chromaffin cells. J. Biol. Chem. 261: 4915-4920.

Guidotti, A., and E. Costa (1973) Involvement of adenosine 3,5monophosphate in the activation of tyrosine hydroxylase elicited by drugs. Science 179: 902-904.

Gutman, Y., and P. Boonyavivoj (1979) Activation of adrenal medulla adenylate cyclase and catecholamine secretion. Naunyn Schmiedebergs Arch. Pharmacol. 307: 39-44.

Jannus, S. D., and R. P. Rubin (1976) Analysis of the role of cyclic adenosine 3,5-monophosphate in catecholamine release. J. Physiol 237: $465-476$.

Kikkawa, U., Y. Minakuchi, Y. Takai, and Y. Nishizuka (1983) Calcium-activated, phospholipid-dependent protein kinase (protein kinase C) from rat brain. Methods Enzymol. 99: 288-298.

Kirpekar, S. M. (1975) Factors influencing transmission at adrenergic synapses. Prog. Neurobiol. 4: 163-220.

Malhotra, R. K., and A. R. Wakade (1987a) Noncholinergic component of rat splanchnic nerves predominates at low neuronal activity and is eliminated by naloxone. J. Physiol. 383: 639-652.

Malhotra, R. K., and A. R. Wakade (1987b) Vasoactive intestinal polypeptide stimulates the secretion of catecholamines from the rat adrenal gland. J. Physiol. 388: 285-294.

Malhotra, R. K., S. V. Bhave, T. D. Wakade, and A. R. Wakade (1988a) Protein kinase $C$ of sympathetic neuronal membrane is activated by phorbol ester-Correlation between transmitter release ${ }^{45} \mathrm{Ca}^{2+}$ uptake, and the enzyme activity. J. Neurochem. 51: 967-976.

Malhotra, R. K., T. D. Wakade, and A. R. Wakade (1988b) Vasoactive intestinal polypeptide and muscarine mobilize intracellular $\mathrm{Ca}^{2+}$ through breakdown of phosphoinositides to induce catecholamine secretion: Role of $\mathrm{IP}_{3}$ in exocytosis. J. Biol. Chem. 263: 2123-2126.

Malhotra, R. K., T. D. Wakade, and A. R. Wakade (1988c) Comparison of secretion of catecholamines from the rat adrenal medulla during continuous exposure to nicotine, muscarine or excess $\mathrm{K}$. Neuroscience 26: 313-320, 2123-2126.

McHugh, E. M., and R. J. McGee (1986) Direct anesthetic-like effects of forskolin on the nicotinic acetylcholine receptors of PC12 cells. J. Biol. Chem. 261: 3103-3106.

Misbahuddin, M., M. Oka, A. Nakanishi, and K. Morita (1988) Stimulatory effect of vasoactive intestinal polypeptide on catecholamine secretion from isolated guinea pig adrenal chromaffin cells. Neurosci. Lett. 92: 202-206.

Morita, K, T. Dohi, S. Kitayama, Y. Koyama, and A. Tsujimoto (1987a) Enhancement of stimulation evoked catecholamine release from cultured bovine adrenal chromaffin cells by forskolin. J. Neurochem. 48 : 243-247.

Morita, K., T. Dohi, S. Kitayama, Y. Koyama, and A. Tsujimoto (1987b) Stimulation-evoked $\mathrm{Ca}^{2+}$ fluxes in cultured bovine adrenal chromaffin cells are enhanced by forskolin. J. Neurochem. 48: 248252.

Oka, M., M. Isosakai, and S. Watanabe (1982) Calcium flux and catecholamine release in isolated bovine adrenal medullary cell: Effects of nicotinic and muscarinic stimulation. Adv. Biol. Sci. 36: 2936.

Peach, M. J. (1972) Stimulation of release of adrenal catecholamine by adenosine 3,5-cyclic monophosphate and theophyllin in the absence of extracellular $\mathrm{Ca}^{2+}$. Proc. Natl. Acad. Sci. USA 69:834-836.

Pozzan, T., G. Gatti, N. Dozio, L. M. Vincentini, and J. Meldolisi (1984) $\mathrm{Ca}^{2+}$-dependent and independent release of neurotransmitters from PC1 2 cells: A role for protein kinase $\mathrm{C}$ activation. J. Cell Biol. 99: 628-638.

Rabe, C. S., E. Delorme, and F. F. Weight (1987) Muscarine-stimulated neurotransmitter release from PC12 cells. J. Pharmacol. Exp. Ther. 2432: 534-541.

Schacterle, G. R., and R. L. Pollack (1983) A simplified method for the quantitative assay of small amounts of protein in biological material. Anal. Biochem. 51: 654-655.

Schneider, A. S., H. T. Cline, and S. Lemaire (1979) Rapid rise in 
cyclic GMP accompanies catecholamine secretion in suspensions of isolated adrenal chromaffin cells. Life Sci. 24: 1389-1394.

Sorimachi, M., S. Nishimura, and K. Yanu (1985) Tumor promoters potentiate the adrenomedullary secretion induced by acetylcholine and excess $\mathrm{K}$ possibly by stimulating phorbol ester receptors. J. Physiol. 35: 175-178.

Tsujimoto, A., K. Morita, S. Kitayama, and T. Dohi (1986) Facilitation of acetylcholine-evoked catecholamine release by cyclic AMP on isolated perfused dog adrenal glands. Arch. Int. Pharmacodyn. Ther. 279: 304-313.

Vincentini, L. M., A. Ambrosini, F. Divigillio, T. Pozzan, and J. Meldolesi (1985) Muscarinic receptor-induced phosphoinositide hydrolysis at resting cytosolic $\mathrm{Ca}^{2+}$ concentration in PC12 cells. J. Cell Biol. 100: 1330-1333.

Wakade, A. R. (1981a) Studies on secretion of catecholamines evoked by acetylcholine or transmural stimulation of the rat adrenal. J. Physiol. 313: 463-480.

Wakade, A. R. (1981b) Facilitation of secretion of catecholamines from rat and guinea pig adrenal glands in potassium-free medium or after ouabain. J. Physiol. 313: 481-498.
Wakade, A. R. (1987) Nicotinic and muscarinic regulation of adrenal chromaffin secretion. In Tobacco Smoking and Nicotine, W. R. Martin, G. R. V. Loon, E. T. Iwamoto, and L. Davis, eds., Plenum, New York.

Wakade, A. R. (1988) Noncholinergic transmitter(s) maintains secretion of catecholamines from rat adrenal medulla for several hours of continuous stimulation of splanchnic neurons. J. Neurochem. 50: 1302-1308.

Wakade, A. R., and T. D. Wakade (1983) Contribution of nicotinic and muscarinic receptors in the secretion of catecholamines evoked by endogenous and exogenous acetylcholine. Neuroscience 10: 973978.

Wakade, A. R., R. K. Malhotra, and T. D. Wakade (1986) Phorbol ester facilitates $\mathrm{Ca}^{45}$ accumulation and catecholamine secretion by nicotine and excess $\mathrm{K}$ but not by muscarine in the rat adrenal medulla. Nature 321: 698-700.

Wakade, A. R., T. D. Wakade, R. K. Malhotra, and S. V. Bhave (1988) Excess $\mathrm{K}^{+}$and phorbol ester activate protein kinase $\mathrm{C}$ and support the survival of chick sympathetic neurons in culture. J. Neurochem. 51: 975-983. 